\title{
KARAKTERISTIK FENOTIP DAN GENOTIP MIKROSIMBION SPONS NIPHATES SP SEBAGAI BIOMATERIAL POTENSIAL PENDEGRADASI POLI AROMATIK HIDROKARBON
}

\author{
Ismail Marzuki $^{1)}$, Sinardi ${ }^{1)}$, Asmeati $^{2)}$ \\ 1) Dosen Teknik Kimia, Fakultas Teknik, Universitas Fajar, Makassar \\ 2) Dosen Teknik Mesin, Fakultas Teknik, Universitas Fajar, Makassar
}

\begin{abstract}
Sponges are often used as a reference for pollutant bioindicators, (pollution of heavy metals and poly aromatic hydrocarbons. Porosity of the sponge body is used as host microorganisms, especially bacteria and fungi. Phenotypic characterization and symbiotic genotypes of Niphates sp. molecular rRNA gene 2 of Nephates sp as symbionts isolates showed a positive reaction to methyl red (acid producer), VR, citrate (has a genetic carrier enzyme), lactose and catalase (acidic). This data shows that both isolates of Niphates sp can make carbon as a nutrient source of energy: Genotypic analysis of 2 isolates of Nephates sp in the phases of amplification and alignment of the sample gene homolog series on the Bank gene concluded that the 2 isolates were Bacillus cohnii strain DSM 6307 (BC) and Bacillus pumilus strain GLB197 (BP). (Fenantrena) shows growth cell cells based on parameters of increased optical density, gas bubbles formed, changes in media $\mathrm{pH}$ and fermentation odor arises.
\end{abstract}

Keywords: sponge, microsymbiont, phenotype, genotype, biodegradation, PAH

\section{PENDAHULUAN}

Populasi, sebaran dan jenis spons Indonesia mencapai $65 \%$ dari potensi dunia. Spons salah satu kekayaan laut, harus bermanfaat tinggi untuk kemaslahatan ummat manusia terutama sebagai sumber pengetahuan dan penghasil senyawa spesifik berpotensi bahan primer dan sekunder untuk obat dan kosmetik, produsen dan kemampuan symbiosis berbagai macam mikroorganisme yang memiliki dua fungsi utama, yakni sebagai biodegradator PAH dan bioabsoprsi logam berat. Patut disayangkan karena potensi besar kekayaan hayati dalam pemanfaatannya di Indonesia belum maksimal sebagai sumber pengetahuan baru dan pemanfaatan sebagai sumber material tertentu. Eksplorasi dan eksploitasi spons di Indonesia baru tahap identifikasi, karakterisasi, isolasi, serta ekstrasi komponen kimia untuk tujuan tertentu dan sebagai objek pada destinasi wisata.

Beberapa metode yang telah diterapkan dalam penanganan limbah sludge minyak bumi termasuk jika terjadi insiden tumpahan minyak bumi akibat kecelakaan kapal tanker, kebocoran pipa distribusi minyak bumi, kegiatan transportasi laut dan darat dan sumber lainnya, seperti metode fisika (hanya mmperlambat sebaran limbah, tidak mengurangi sifat racun), kimia (biaya yang mahal dan efek negatif bagi organisme lain sekitarnya) dan biologi (membutuhkan waktu cukup lama, hanya untuk skala kecil dan produk hasil olahan bersifat sementara), sehingga disimpulkan bahwa metode fisika, kimia dan biologi kurang efisien digunakan dalam menangani pencemaran limbah PAH, (Abubakar, 2009; Tam et al., 2008)

Tingkat kehidupan berbagai biota laut dan terumbu karang sebagai bioindikator tingkat pencemaran yang terjadi di laut. Jenis pencemaran yang paling berpengaruh terhadap kelangsungan hidup berbagai biota dan terumbu karang adalah pencemaran logam berat, hidrokarbon khususnya golongan Poli Aromatik Hidrokarbon $(\mathrm{PAH})$ dan akumulasi sampah plastik, gangguan kekeruhan akibat pergerakan arus laut, dasar laut yang berlumpur atau mungkin karena adanya perubahan fisik area laut oleh reklamasi serta masalah penggunaan bahan peledak dalam melakukan penangkapan ikan di laut. Biota seperti spons sangat sangat terganggu oleh kekeruhan dan tumpukan sampah plastik, karena kebanyakan populasi spons pada wilayah laut dangkal. Pencemaran logam berat pada tingkat tertentu dan akumulasi PAH karsinogenik dan mutagenik tetap berdampak buruk terhadap kehidupan spons, meskipun pada tubuh spons diduga mengandung zat menyerupai perilaku enzim yang dapat bertindak sebagai bioabsoprsi beberapa jenis logam berat dan juga mampu sebagai biodegradator komponen kimia hidrokarbon, (Marzuki et al. 2014a; Syakti et al., 2013).

Kemampuan simbion spons merombak struktur hidrokarbon menimbulkan berbagai pertanyaan kritis ilmiah sebagai bagian dari permasalahan penelitian yang memerlukan pemecahan, diantaranya: 1) spesies spons dan jenis mikrosimbion yang dapat mendegradasi hikrokarbon, 2) bagaimana mekanisme degradasi

\footnotetext{
${ }^{1}$ Korespondensi penulis: Ismail Marzuki, Telp 081241011873, ismailmz@unifa.ac.id
} 
yang terjadi, 3) kecepatan mikrosymbion tersebut dalam merombak komponen kimia hidrokarbon, 4) kondisi yang dibutuhkan untuk terjadinya proses degradasi spons/mikrosimbion dalam mereduksi sifat toksik hidrokarbon. Permasalahan tersebut dapat dipecahkan dengan melakukan sejumlah analisis sebagai tujuan penelitian yakni: menentukan spesies mikrosimbion, mekanisme degradasi, kecepatan proses degradasi dan parameter yang menentukan degradasi dapat berlangsung maksimal. Kajian degradasi PAH menggunakan mikrosymbion urgen dilakukan mengingat bahwa beberapa jenis PAH bersifat karsinogenik, mutagenik dan toksisitas tinggi, sehingga sangat membahayakan kehidupan terhadap biota laut dan dapat terakumulasi hingga masuk dalam siklus rantai makanan yang akhirnya dapat menjadi masalah kronik terhadap kesehatan manusia. Potensi ancaman yang dapat timbul akibat percemaran PAH baik dilaut maupun pada daratan, sehingga penelitian ini sangat urgen untuk dilakukan, terlebuh lagi bahwa populasi spons Indonesia cukup besar termasuk spons pada Kepulauan Spermonde khsusnya sekitar kepulauan Selat Makassar. Degradasi hidrokarbon dengan memanfaatkan mikroorganisme sebelumnya telah dilakukan menggunakan isolat dari mangrove, (Marzuki et al., 2015b; 2015c; Syakti, et at., 2013; Tam N.F.Y., Wong, 2008), sedangkan spons sebagai bioindikator pencemaran banyak dilakukan sebelumnya, (Venkateswara et al., 2009)

\section{METODE PENELITIAN}

\section{a. Material dan peralatan}

Material yang digunakan dalam penelitian ini adalah isolat spons Niphates sp, Media NA, reagen uji biokimia standar, $\mathrm{CH} 3 \mathrm{OH}$ pa, air laut steril, Phosphate Buffer Saline (PBS), Sea Water Complit (SWC), marine agar (MA), 25\% gliserol, mikro-simbion sponge isolat, formalin 4\%, Aqubides, ddH2O, chelex $20 \%$, sepasang sekuens primer universal gen 16S rRNA E. coli: FP-U1 (5'-CCAGCAGCCG CGGTAATACG-3') pada nucleotides 518-537, dan RP-U2 adalah (5'-ATCGG (C/T) TACCTTGT TACGACTTC-3') sesuai dengan nukleotida 1513-1491, DNA template, Taq DNA polymerase (Perkin-Elmer, Norwalk, Conn), PCR Mix, Triton X-100, Tris, EDTA, $\mathrm{HCl}, \mathrm{KCl}, \mathrm{MgCl}_{2}$, parafin, tripofosfat deoxynucleoside, gel poliakrilamida, agarose, Ethidium Bromide, dichloromethana GR merck, methanol, Fenantrena GR, standar iso-oktan konsentrasi $691 \mathrm{ug} / \mathrm{mL}$ (CA540-84-1 ), standar TCL PAH $162000 \mu \mathrm{g} / \mathrm{mL}$, Stone Mineral Salt Solution (SMSS): komposisi 1,8 g K2HPO4; $1,2 \mathrm{~g} \mathrm{KH}_{2} \mathrm{PO}_{4} ; 4,0 \mathrm{~g} \mathrm{NH} 4 \mathrm{Cl} ; 0,2 \mathrm{~g}, \mathrm{MgSO}_{4} .7 \mathrm{H}_{2} \mathrm{O} ; 0,1 \mathrm{~g} \mathrm{NaCl} ; 0,01 \mathrm{~g}$ $\mathrm{FeSO}_{4} \cdot 7 \mathrm{H}_{2} \mathrm{O}$; dan $1.000 \mathrm{~mL}$ air suling), $0,9 \% \mathrm{NaCl}$ fisiologis.

Peralatan yang digunakan: pisau bedah, tang, pial, mikroskop haemositometer, cangkir porselen, mortir dan alu, blender, seperangkat gelas, bunsen, keseimbangan analitis, hot plate, hisap karet, Whatman, oven, freezer, botol BOD, termometer, ose bulat, effendorf $1,5 \mathrm{~mL}$ tabung, vortex shaker, disentrifugasi 1000 rpm, $4000 \mathrm{rpm}$ dan $10.000 \mathrm{rpm}$, sendok media, pengaduk, compactor container gel, kertas $\mathrm{pH}$ universal, salinometer, stop watch, aliran air laminer (LAF), autoclove, filter $0.2 \mathrm{~lm}$, mesin PCR (Biorad), program Bioedit, MAS-100 (Microbio-logical Air Sampler), mikropipet, filter ujung, pengendara sepeda gen, gel doc, dan elektroforesis.

\section{b. Tahapan Aktivitas Penelitian}

Metode yang diterapkan dalam pencapaian tujuan penelitian dengan melakukan tahapan kegiatan pemilihan spons Niphates sp hasil analisis fisiologi dan morfologi, isolasi mikrosimbion, analisis morfologi isolat, kultur simbion, analisis genotip, pembuatan suspensi simbion dan kontak suspensi simbion dengan jenis PAH tertentu untuk melihat kinerja simbion dan pengamatan terhadap parameter degradasi yang terjadi, lebih ringkas disajikan dalam Gambar 1. Diagram Alir, sebagai berikut: 


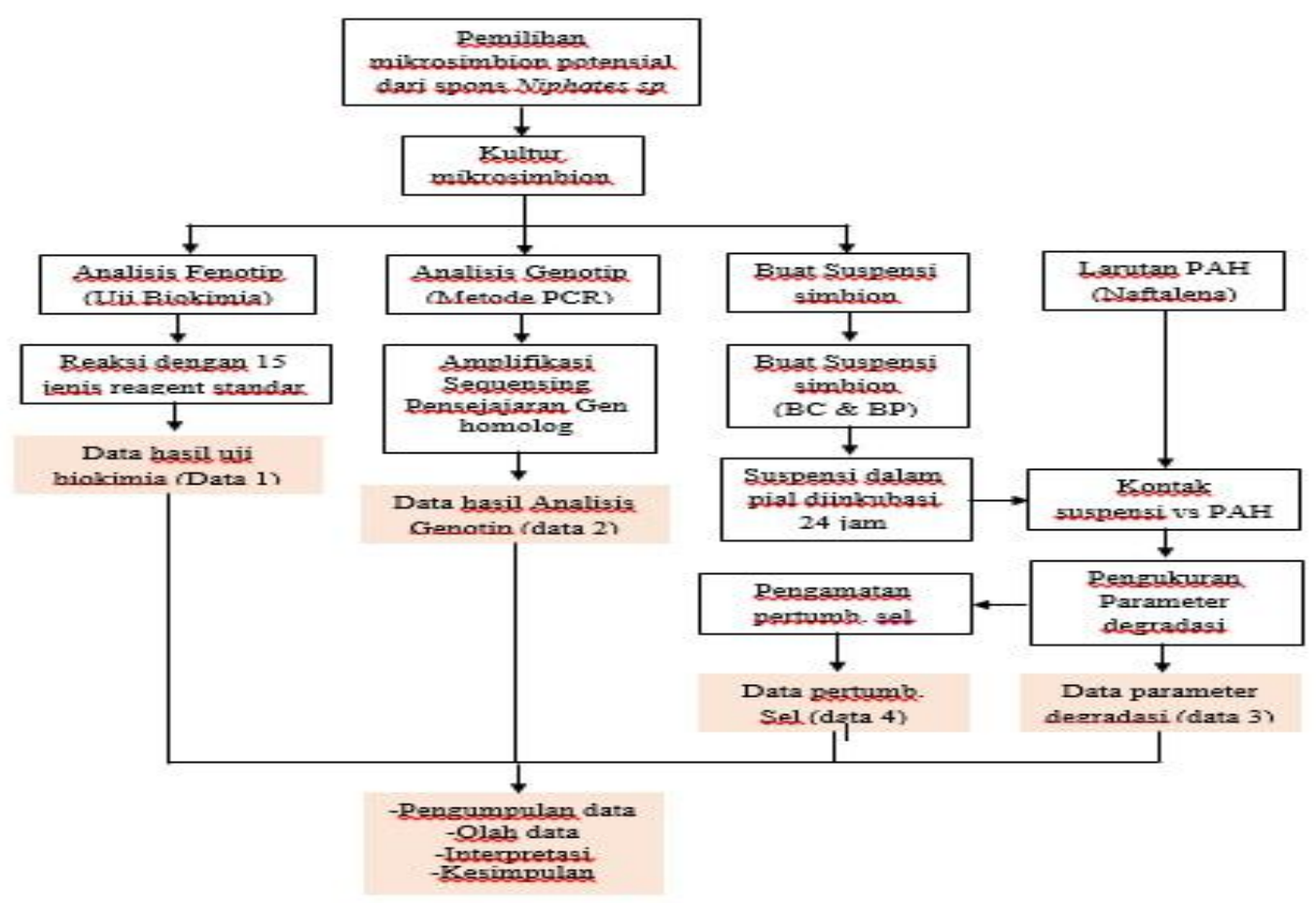

Gambar 1. Diagram alir tahapan dan Aktivitas Penelitian

\section{HASIL DAN PEMBAHASAN}

\section{a. Analisis Fenotip Mikrosimbion Spons}

Pemilihan isolat dari spons didasarkan pada morfologi dilokasi habitatnya yakni spons yang pada bagian tubuhnya tertutup oleh lendir dengan alasan bahwa lendir yang diproduksi oleh spons sebagai bentuk mempertahankan diri dari ancaman predator termasuk pencemaran PAH. Niphates sp adalah salah satu spons yang seluruh permukaan tubuhnya tertutup oleh lendir. Jumlah isolat dari Niphates sp ada 2 jenis, keduanya merupakan isolat gram negatif berbentuk basil memanjang (isolat 1) dan basil tidak memanjang (isolat 2). Hasil analisis fenotip kedua simbion Niphates $s p$ yakni bereaksi positif dengan kaldu laktosa dalam media fermentasi menunjukkan bahwa kedua isolat bersifat asam, demikian pula hasil reaksi positif pada uji katalase dalam media NA miring. Reaksi positif pada uji sitrat menggambarkan bahwa isolat tersebut memiliki enzim pembawa sifat genetic. Hal yang sama diperoleh rhasil reaksi positif terhadap reagent MR dan VR, yang berarti bahwa kedua isolat bersifat asam, (Marzuki et al., 2014b; 2016; Ismet et al., 2011; Hamzah et al., 2010; Ijah, 2008).

\section{b. Analisis Genotip Mikrosimbion Spons}

Analisis genotip isolat Niphates $s p$ dilakukan dengan cara amplifikasi sel menggunakan metode Polimerase Chain Reaction (PCR) dimaksudkan melihat susunan dan jumlah gen kedua isolat spons dengan mensejajarkan homolog gen sampel terhadap gen Bank melalui analisa BLAST (Basic Local Alignment Search Tool). Ringkasan hasil BLAST disajikan dalam Tabel 1, berikut:

Tabel 1. Hasil BLAST (Basic Local Alignment Search Tool) Bakteri

\begin{tabular}{|c|c|c|c|c|c|c|}
\hline No & Sampel & $\begin{array}{c}\text { Sekuen } \\
\text { Sampel }\end{array}$ & Sekuen GenBank & $\begin{array}{c}\text { Identitas } \\
(\mathbf{\%})\end{array}$ & $\begin{array}{c}\text { Signifikansi } \\
(\mathbf{\%})\end{array}$ & Spesies \\
\hline 1 & 2 & 3 & 4 & 5 & 6 & 7 \\
\hline & & & $608.723-609.672$ & $911 / 951$ & $40 / 951$ & Bacillus cohnii strain \\
1 & Isolat 1 & $21-910$ & $(949)$ & $(96,90 \%)$ & $(4,10 \%)$ & DSM 6307 (BC) \\
\hline & & & $541-1477$ & $922 / 956$ & $34 / 956$ & Bacillus pumilus strain \\
2 & Isolat 2 & $15-913$ & $(936)$ & $(96,45 \%)$ & $(3,55 \%)$ & GLB197 (BP) \\
\hline
\end{tabular}

Hasil pensejajaran dengan membandingkan sekuen sampel terhadap sekuen gen bank dengan identitas masing-masing isolat pertama: 911/951(96,90\%) dan isolat kedua 922/956 (96,45\%), 
menunjukkan bahwa kedua isolat tersebut merupakan golongan basilus dengan spesifikasi dan strain seperti pada Tabel 1 kolom 7, (Marzuki et al., 2015; 2014a; Alamri, 2012; Abubakar, 2011; Cai et al., 2007).

c. Komposisi Media Degradasi Suspensi Simbion Niphates sp

Komposisi suspensi isolat simbion Niphates $s p$ yang digunakan sebagai media untuk melihat aktivitas pertumbuhan sel dalam media terkontaminasi Fenantrena dapat dilihat dalam Tabel 2, berikut:

Tabel 2. Komposisi dan Kondisi Media Uji Pertumbuhan/aktivitas Sel dalam limbah PAH oleh Mikrosymbion Niphates $s p$

\begin{tabular}{|c|l|c|c|c|c|}
\hline \multirow{2}{*}{ No } & \multirow{2}{*}{$\begin{array}{c}\text { Uraian komponen } \\
\text { media }\end{array}$} & \multicolumn{4}{|c|}{ Jenis bakteri simbion Spons Niphates sp } \\
\cline { 2 - 6 } & BC & BP & PS & K. Negatif \\
\hline 1 & Media pertumbuhan & SMSS & SMSS & SMSS & SMSS \\
\hline 2 & $\begin{array}{l}\text { V. media } \\
\text { pertumbuhan }\end{array}$ & $10 \mathrm{~mL}$ & $10 \mathrm{~mL}$ & $10 \mathrm{~mL}$ & $10 \mathrm{~mL}$ \\
\hline 3 & Jumlah sel bakteri & $\begin{array}{c}4,8.10^{3} \\
\text { sel/mL }\end{array}$ & $\begin{array}{c}3,3.10^{4} \\
\text { sel/mL }\end{array}$ & $\begin{array}{c}1,5.10^{1} \mathrm{sel} / \mathrm{m} \\
\mathrm{L}\end{array}$ & $0 \mathrm{sel} / \mathrm{mL}$ \\
\hline 4 & Volume suspensi & $10 \mathrm{~mL}$ & $10 \mathrm{~mL}$ & $10 \mathrm{~mL}$ & $10 \mathrm{~mL}$ \\
\hline 5 & pH media & 7 & 7 & 6,5 & 7 \\
\hline 6 & Temperatur kerja & Suhu kamar & suhu kamar & suhu kamar & suhu kamar \\
\hline 7 & Waktu kontak & \multicolumn{2}{|c|}{25 hari (setiap 5 hari dilakukan pengukuran) } \\
\hline 8 & Kondisi kerja & aseptik & aseptik & aseptik & aseptik \\
\hline
\end{tabular}

Pengamatan aktivitas sel isolat dalam media degradasi terkontaminasi penantrena dilakukan dengan menentukan komposisi dan kondisi awal media degradasi dan penggunaan kontrol positif Pseudomonas $s p$ dan control negatif, seperti pada Tabel 2 di atas. Hal ini dimaksudkan untuk memastikan bahwa tidak ada material yang tercampur dalam suspensi kecuali isolat, sehingga perubahan-perubahan yang terjadi hanya disesbabkan oleh kerja isolat simbion terhadap degradasi fenantrena, (Marzuki et al., 2015b; Ijah, 2008).

\section{d. Parameter Degradasi PAH}

Tabel 3, dan Tabel 4, merupakan hasil pengamatan parameter degradasi oleh simbion spons Niphates $s p$ yang di tempatkan dalam media terkontaminasi fenantrena.

Tabel 3. Pembentukan Gelembung Gas dan Bau Fermentasi Media Degradasi Berdasarkan Waktu kontak Suspensi Simbion Niphates $s p$ terhadap PAH

\begin{tabular}{|c|c|c|c|c|c|l|}
\hline \multirow{2}{*}{ No } & \multirow{2}{*}{ Suspensi } & \multicolumn{4}{|c|}{ Perlakuan dan waktu kontak (hari) } & \multirow{2}{*}{ Keterangan } \\
\cline { 3 - 6 } & & Perl. 1 & Perl. 2 & Perl. 3 & Perl. 4 & pembentukan gelembung gas \\
\hline \multirow{2}{*}{1} & \multirow{2}{*}{ Isolat BC } & 10 & 15 & 15 & 20 & pement \\
\cline { 3 - 7 } & & 15 & 20 & 15 & 25 & bau fermentasi \\
\hline \multirow{2}{*}{2} & \multirow{2}{*}{ Isolat BP } & 10 & 10 & 15 & 15 & pembentukan gelembung gas \\
\cline { 3 - 7 } & & 15 & 20 & 20 & 20 & bau fermentasi \\
\hline \multirow{2}{*}{3} & Isolat PS & 10 & 15 & 15 & 15 & pembentukan gelembung gas \\
\cline { 3 - 7 } & (K. Positif) & 15 & 15 & 15 & 20 & bau fermentasi \\
\hline
\end{tabular}

Keterangan:

Perl. 1 = Sampel di Shaker pasa suhu kamar

Perl.2 = Sampel tidak di Shaker pasa suhu kamar

Perl.3 = Sampel di Shaker pada suhu $25^{\circ} \mathrm{C}$

Perl.4 = Sampel tidak di Shaker dan ditmpatlan pada suhu $25^{\circ} \mathrm{C}$

Pembentukan gelembung gas pada hari ke 10 (perlakuan 1) untuk semua jenis isolat menunjukkan adanya aktivitas sel simbion spons, sedangkan bau fermentasi teridentifikasi dengan waktu yang ada bervariasi antara isolat disebabkan karena kinerja isolat satu terhadap lainnya berbeda dalam proses degradasi fenantrena. 
Tabel 4. Perubahan $\mathrm{pH}$ Media Degradasi Berdasarkan Waktu Kontak Symbion Niphates sp terhadap PAH

\begin{tabular}{|c|c|c|c|c|c|c|c|}
\hline \multirow{2}{*}{ No } & \multirow{2}{*}{ Suspendi } & \multicolumn{7}{|c|}{ Waktu kontak (hari) } \\
\cline { 2 - 8 } & Isolat BC & 7 & $\mathbf{5}$ & $\mathbf{1 0}$ & $\mathbf{1 5}$ & $\mathbf{2 0}$ & $\mathbf{2 5}$ \\
\hline 1 & Isolat BP & 7 & 6 & 6 & 6 & 6 & 7 \\
\hline 2 & 7 & 6 & 6 & 6 & 6 & 7 \\
\hline 3 & Isolat PS (K. Positif) & 7 &
\end{tabular}

Tabel 4, di atas terlihat perubahan pH menjadi 6 pada hari ke 5 dan ke 10 masa kontak menunjukkan bahwa ada aktivitas sel simbion Niphates $s p$. Aktivitas sel ini berupa penambahan ukuran dan penambahan jumlah sel, sehingga $\mathrm{pH}$ media degradasi mengalami perubahan ke sifat lebih asam, Hasil ni sejalan dengan penelitian sebelumnya, (Marzuki et al., 2015b; 2015c; Hamzah et al., 2010).

Tabel 5. Kerapatan Optik Media Degradasi Berdasarkan Waktu Kontak (hari)

\begin{tabular}{|c|c|c|c|c|c|}
\hline & \multirow{2}{*}{ No. } & Waktu Kontak & \multicolumn{4}{|c|}{ Optical Density (OD) } \\
\cline { 3 - 6 } & (hari) & Isolat BC & Isolat BP & PS (K.Positif & K. Negatif \\
\hline 1 & 0 & 0.008 & 0.007 & 0.007 & 0.002 \\
\hline 2 & 5 & 0.027 & 0.029 & 0.031 & 0.003 \\
\hline 3 & 10 & 0.089 & 0.092 & 0.095 & 0.003 \\
\hline 4 & 15 & 0.121 & 0.120 & 0.124 & 0.004 \\
\hline 5 & 20 & 0.129 & 0.128 & 0.126 & 0.005 \\
\hline 6 & 25 & 0.133 & 0.131 & 0.131 & 0.006 \\
\hline
\end{tabular}

Berdasarkan Tabel 5, di atas menunjukkan adanya peningkatan kekeruhan media degradasi, dimana kekeruhan tersebut diakibatkan oleh beberapa faktor, diantaranya: 1) bertambahanya ukuran sel isolat; 2) Jumlah sel isolat meningkat karena terjadi pembelahan sel yang diperkirakan terjadi pada masa kontak 10 hari ke atas; 3) terbentuk senyawa organik sederhana seperti gas methana dan $\mathrm{CO}_{2}$, hasil degradasi perombakan struktur fenantrena oleh isolat. Tabel 5 , di atas juga memperlihatkan terjadinya penurunan kerapan optik pada masa kontak mulai hari ke 20 hingga hari ke 25, diperkirakan terjadi akibat sebagian dari sel isolat mati dan tidak lagi mampu melakukan pembelahan diri, (Meutia et al., 2011; Murniasih et al., 2010; Lin et al., 2008). Matinya sel isolat tersebut karena sel-sel ini tidak mampu bertahan lebih lama akibat toksisitas dari fenantrena, sedangkan sel tidak lagi membela disebabkan karena media degradasi mengalami perubahan $\mathrm{pH}$ atau media tidak berada pada kondisi optimum untuk terjadinya pembelahan sel, Hasil ini sejalan dengan penelitian sebelumnya, (Marzuki et al., 2015c; Acevedo et al., 2011; Komarawidjaja 2009).

\section{KESIMPULAN} berikut:

Karakteristik fenotip, genotip dan data parameter degradasi, dapat disimpulkan beberapa hal sebagai

1. Karakteristik fenotip dua isolat spons Niphates $s p$ adalah bereaksi positif dengan reagent katalase, laktase (bersifat asam), methyl merah (penghasil asam), citrate (memiliki enzim sebagai pembawa sifat genetik.

2. Karakteristik genotip berdasarkan data sekuen sampel terhadap pensejajaran homolog sekuen gen bank, kedua isolat merupakan jenis basillus dengan spesies masing-masing isolat pertama adalah Bacillus cohnii strain DSM 6307 (BC) dan isolat nomor 2 adalah Bacillus pumilus strain GLB197 (BP)

3. Kedua isolat Niphates sp tersebut mampu mendegradasi PHA jenis fenantrena yang didasarkan pada data parameter degradasi yakni perubahan $\mathrm{pH}$ media, bau fermentasi, kerapatan optik dan gelembung gas.

\section{DAFTAR PUSTAKA}

Abubakar, H., Wahyudi, T. A., Yuhana, M., 2011. Skrining bakteri yang berasosiasi dengan spons Jaspis sp. sebagai penghasil senyawa antimikroba. Jurnal Ilmu Kelautan, vol. 16 (1):35-40

Acevedo, Francisca, Leticia Pizzul, María del Pilar Castilloc, Raphael Cuevas, María, C. Diez. 2011. Degradation of polycyclic aromatic hydrocarbons by the Chilean white-rot fungus Anthracophyllum discolor. J. of Hazardous Materials, vol. 185:212-219

Alamri, A. Saad, 2012. Biodegradation of microcystin-RR by Bacillus flexus isolated from a Saudi freshwater lake. Published online- doi:10.1016/j ssjbs.2012.06.006. Saudi Journal Biol Sci, vol. 19 (4):435-440 
Cai, Quan-Ying, Ce-Hui Mo, Qi-Tang Wu, Qiao-Yun Zeng, Athanasios Katsoyiannis, Jean-Francois F'erard, 2007. Bioremediation of polycyclic aromatic hydrocarbons (PAHs)-contaminated sewage sludge by different composting processes. Journal of Hazardous Materials, vol. 142:535-542

Hamzah, A., Rabu, A., Farzarul, R., Azmy, R.H., 2010. Isolation and characterization of bacteria degrading Sumandak and South Angsi Oils. Jurnal Sains Malaysiana, vol. 39 (2):161-168

Ijah U. J. J., and L. I. Ukpe. 2008. Biodegradation of Crude Oil by Bacillus Strain 28A and 61B Isolated from Oil Spilled Soil. Waste Management Journal vol. 12:55-60

Ismet, S.M., Soedharma, D., Effendi, H., 2011. Morphology and cell biomass of sponge Aaptos aaptos and Petrosia sp., J. Ilmu Tek.Kelautan Tropis. vol. 3 (2): 153-161

Komarawidjaja, W., 2009. Karakteristik dan pertumbuhan konsorsium mikroba lokal dalam media mengandung minyak bumi, Jurnal Teknologi Lingkungan, vol. 10 (1): 114-119

Lin, Y., and L. X. Cai, 2008. PAH-degrading microbial consortium and its pyrene-degrading plasmids from mangrove sediment samples in Huian, China. Marine Pollution Bulletin, vol. 57:703-706

Marzuki, I., Noor, A., Djide, N.M., La Nafie, N., 2014a. Isolation and Identification on Degradator Bacterial of Petroleum waste which Symbionts with Sponge Callyspongis sp from Melawai Beach. Proceeding: International Confrence on the sciences (ICOS), 19-20 Nopember 2014, Makassar, ISBN : 9786027219809, pp. 493-503, DOI: 10.17605/OSF.IO/PZVKC

Marzuki, I., Noor, A., Djide, N.M., La Nafie, N., 2014b. Isolation and identification Bacterial Symbionts of sponge as Producer enzyme amylase from Melawai Beach, Balikpapan, Jurnal dr.Aloei Saboe, vol.1 (1):11-18, DOI : 10.17605/OSF.IO/R4JYA

Marzuki, I., Noor, A., Djide, N.M., La Nafie, N., 2015a, Molecular characterization of gene 16S rRNA micro symbionts in sponge at Melawai Beach, East Kalimantan, Journal Marina Chimica Acta, 16 (1):38-46, DOI: $10.17605 / O S F . I O / X K P 9 B$

Marzuki, I., Noor, A., Djide, N.M., La Nafie, N., 2015b, The potensi biodegradation hydrocarbons of petroleum sludge Waste by cell biomassa sponge Callyspongia sp, Journal Marina Chimica Acta, 16 (2):11-20, DOI: 10.17605/OSF.IO/RCNDW

Marzuki, I., Noor, A., Djide, N.M., La Nafie, N., 2015c, Sponge role in alleviating oil pollution through sludge reduction, a preliminary approach, Int. Journal of Applied Chemistry, 11 (4):427-441, DOI: 10.17605/OSF.IO/S9HTG

Marzuki, I., Noor, A., Djide, N.M., La Nafie, N., 2016. Microsymbiont and Morphological Phenotype Analysis Marine Sponge Biomass From Melawai Beach, Balikpapan, East Kalimantan, Journal Marina Chimica Acta, 17 (1):8-15, DOI: 10.17605/OSF.IO/P73EN

Meutia, S.P., Soedharma, D., Effendi, H., 2011. Morfologi dan biomassa sel spons Aaptos aaptos dan Petrosia sp. Jurnal Ilmu dan Teknologi Kelutan Tropis, vol. 3, (2):153-161

Murniasih. T., dan Rasyid, A., 2010. Potensi bakteri yang berasosiasi dengan spons asal Barrang LompoMakassar sebagai sumber bahan anti bakteri, Jurnal Oseanologi dan Limnologi, vol. 36 (3):281-292

Syakti, D. A., Yani, M., Hidayati, V.N., Siregar, S.A. Doumeng, P., I.M. Sudiana, M., 2013. The Bioremediation potential of hydrocarbonoclastic bacteria isolated from a Mangrove Contaminated by Petroleum Hydrocarbons on the Cilacap Coast, Indonesia. J.Bioremediation, vol. 17 (1):11-20, online. DOI: 10.1080 .731446

Tam, N.F.Y and Wong, Y.S., 2008. Effectiveness of bacterial inoculum and mangrove plants on remediation of sediment contaminated with polycyclic aromatic hydrocarbons, Marine Pollution Bulletin, vol. 57:716-728

Venkateswara, Rao, J., K. Srikanth., Usman, P.K., 2009. The Use of marine sponge, haliclona tenuiramosa as bioindicator to monitor heavy metal pollution in The Coasts of Gulf Mannar, India. Environ Monit Assess, Journal Springer, vol. 156: 451-459

\section{UCAPAN TERIMA KASIH}

Ucapan terima kasih disampaikan kepada Direktorat Riset dan Pengabdian Kepada Masyarakat Direktorat Jenderal Penguatan Riset dan Pengembangan Kemenristekdikti, yang telah memberikan pendanaan dalam pelaksanaan penelitian ini. 